\title{
Organic carbon, water repellency and soil stability to slaking under different crops and managements: a case study at aggregate and intra-aggregate scales
}

A. Jordán ${ }^{1}$, J. García-Moreno ${ }^{1}$, Á. J. Gordillo-Rivero ${ }^{1}$, L. M. Zavala ${ }^{1}$, and A. Cerdà ${ }^{2}$

${ }^{1}$ MED_Soil Research Group, Department of Crystallography, Mineralogy and Agricultural Chemistry, University of Seville, 1, 41012, Sevilla, Spain

${ }^{2}$ SEDER Research Group, Department of Geography, University of Valencia, Blasco Ibáñez, 10, 46010, Valencia, Spain

Received: 22 July 2014 - Accepted: 11 August 2014 - Published: 29 August 2014

Correspondence to: A. Jordán (ajordan@us.es)

Published by Copernicus Publications on behalf of the European Geosciences Union.

Organic $\mathbf{C}$ and water repellency

distribution in soil

aggregates

A. Jordán et al.

\section{Title Page}

14

$>1$

\section{4}

Full Screen / Esc

Printer-friendly Version

Interactive Discussion 


\section{Abstract}

This research studies the distribution of organic $\mathrm{C}$ and intensity of water repellency in soil aggregates with different size and in the interior of aggregates from Mediterranean soils under different crops (apricot, citrus and wheat) and management (con5 ventional tilling and no tilling/mulching). For this, undisturbed aggregates were sampled and carefully divided in size fractions $(0.25-0.5,0.5-1,1-2,2-5,5-10$ and $10-15 \mathrm{~mm})$ or peeled to obtain separated aggregate layers (exterior, transitional and interior). Organic $\mathrm{C}$ content in the fine earth fraction of soils under different crops did not show important variations, although it increased significantly from conventionally tilled to mulched soils. The distribution of organic $\mathrm{C}$ content in aggregates with different size varied among soils under different crops, generally increasing with decreasing size. At the intra-aggregate level, organic $\mathrm{C}$ concentrated preferably in the exterior layer of aggregates from conventionally tilled soils, probably because of recent organic inputs or leachates. In the case of mulched soils, higher concentrations were observed, but no significant differences among aggregate regions were found. The intensity of water repellency, determined by the ethanol method, did not show great variations among crops, but increased significantly from conventionally tilled to mulched soils. Coarser aggregates were generally wettable, while finer aggregates showed slight water repellency. Regardless of variations in the distribution of organic $C$ in aggregate layers from conventionally tilled soils, great or significant differences in the distribution of water repellency at the intra-aggregate level were not found in any case. Finally, the intensity of water repellency was much more important than the concentration of organic $C$ in the stability to slaking of aggregates.

\section{Introduction}

25 Water repellency (WR) is a soil property that inhibits or delays water infiltration during periods of time varying between a few seconds and days or weeks. Inhibited or
SOILD

1, 295-325, 2014

Organic $\mathbf{C}$ and water repellency

distribution in soil aggregates

A. Jordán et al.

\section{Title Page}

Abstract Introduction

Conclusions References

Tables Figures

14 4

Full Screen / Esc

Printer-friendly Version

Interactive Discussion 
delayed infiltration rates contribute to enhanced runoff flow, often increasing soil erosion risk (Doerr et al., 2000; Shakesby et al., 2000). Other important consequences are irregular soil wetting patterns, the development of preferential flow paths and accelerated leaching of nutrients (Blackwell, 2000; Leighton-Boyce et al., 2005; Ritsema 5 and Dekker, 1994).

Although low inputs of hydrophobic organic substances and high mineralization rates lead to low degrees of WR in cropped soils, it has been reported that conservative agricultural practices (reduced or no tilling, mulching treatments, etc.) may induce the development of soil WR (Blanco-Canqui and Lal, 2009; Buczko et al., 2006; García10 Moreno et al., 2013; González-Peñaloza et al., 2012). New evidences show that subcritical or slight WR are common states for many soils (Bodí et al., 2013; Buczko et al., 2006; Goebel et al., 2005; Hallett et al., 2001a; Lozano et al., 2013; Urbanek et al., 2007; Zavala et al.,2014).

Many authors have studied the impact of WR at catchment, slope or plot scales (De15 Bano, 2000; Doerr et al., 2000; Jordán et al., 2013). Nevertheless, comparatively few studies have been carried out at particle or aggregate scale. Some researchers have reported variations in persistence or intensity of WR among aggregates with different size. Intra-aggregate heterogeneity of physical, biological and chemical properties have been reported by Dexter (1988), Horn (1990), Horn et al. (1994) and, more recently, by 20 Fan et al. (2013) and Urbanek et al. (2007). This heterogeneity conditions the transport of substances, microbial activity and biochemical processes, including changes in the amount, distribution and chemical properties of organic matter (Urbanek et al., 2007). Soil WR does not only have negative consequences. Some authors have reported positive relationships with, for example, aggregate stability (Mataix-Solera and Doerr, 2004) or carbon sequestration rates (Piccolo and Mbagwu, 1999).

Studies focused on the intra-aggregate distribution of OC and WR are necessary to shed light on the soil processes at a detailed scale. The objectives of this research are to study (i) the OC content and the intensity of WR in aggregates of different sizes. (ii) the intra-aggregate distribution of $O C$ and the intensity of WR and (iii) the structural
SOILD

$1,295-325,2014$

Organic $\mathbf{C}$ and water repellency

distribution in soil aggregates

A. Jordán et al.

Title Page

Abstract Introduction

Conclusions References

Tables Figures

14 $>$ I

4

Back

Full Screen / Esc

Printer-friendly Version

Interactive Discussion 
stability of soil aggregates relative to the OC content and the intensity of WR in soils under different crops (apricot, citrus and wheat) and different treatments (conventional tilling and mulching).

\section{Methods}

\section{$5 \quad 2.1$ Experimental design and soil sampling}

Soil samples were collected from an experimental area in the province of Sevilla (Southern Spain). Climate is Mediterranean type, with warm dry summers and moderately wet cool winters. According to data from the nearby weather station Las Cabezas ( 25 m a.s.l.; $37^{\circ} 1^{\prime} \mathrm{N}, 5^{\circ} 53^{\prime} \mathrm{W}$ ), mean temperature is $17.6^{\circ} \mathrm{C}$, with monthly mean tem10 perature ranging between 9.8 (January) and $26.0^{\circ} \mathrm{C}$ (August). Annual mean rainfall is $449.4 \mathrm{~mm}$, with mean monthly rainfall ranging between 0.9 (July and August) and $79.3 \mathrm{~mm}$ (November). Soils in the studied area are developed from calcareous sandstone, and are classified as Luvic Calcisols and Calcic Luvisols (WRB, 2006). For this study, soil plots under different crops were selected (apricot, citrus and wheat). At each case, two management types were considered: conventional tillage with moldboard plow and mulching (no-tilling and addition of wheat residues at rates varying between 5 and $8 \mathrm{Mg} \mathrm{ha}^{-1}$ year $\left.^{-1}\right)$.

At each sampling site, soil blocks $(50 \mathrm{~cm}$ long $\times 50 \mathrm{~cm}$ wide $\times 10 \mathrm{~cm}$ deep) were carefully collected to avoid disturbance of aggregates as much as possible and transported to the laboratory. At field moist condition, undisturbed soil aggregates were separated. Individual aggregates were arranged in paper trays and air-dried during 7 days under laboratory standard conditions. After air-drying, part of each sample was separated for different analyses: (i) part of the original samples was reserved for soil chemical and physical characterization; (ii) part of the aggregates were carefully measured with a caliper and separated in different size classes $(0.25-0.5,0.5-1,1-2,2-5,5-10$ and $10-15 \mathrm{~mm}$ ) for determination of WR and OC content; (iii) aggregates $10-15 \mathrm{~mm}$ in size
SOILD

1, 295-325, 2014

Organic $\mathbf{C}$ and water repellency

distribution in soil aggregates

A. Jordán et al.

\section{Title Page}

Abstract Introduction

Conclusions References

Tables Figures

14

4

Back

Full Screen / Esc

Printer-friendly Version

Interactive Discussion 
were selected for obtaining aggregate layers and determination of WR and OC content; finally, (iv) aggregates about $10 \mathrm{~mm}$ in size were selected for assessing stability to slaking, WR and OC content.

\subsection{Separation of aggregate layers}

5 Part of coarser aggregates were selected for obtaining aggregate layers. Aggregate layers were separated using the soil aggregate erosion abrasion chamber described by Park and Smucker (2005), shown in Fig. 1a. For this purpose, single air-dried aggregates $(10-15 \mathrm{~mm})$ were placed in the abrasion chamber and rotated in a rotary shaker at $400 \mathrm{rpm}$. The eroded material fell through a $340 \mu \mathrm{m}$ sieve and was collected in a 10 retainer base chamber. During each experiment, the eroded material was weighted periodically to obtain the exterior and transitional layers. Eroded material corresponding to these layers (Fig. 1b) was collected when the percentage of eroded mass reached $33.3 \pm 2$ and $66.7 \pm 2 \%$, respectively (Park and Smucker, 2005).

\subsection{Soil analyses}

15 Part of air-dried soil samples were sieved $(2 \mathrm{~mm})$ to eliminate coarse soil particles and homogenized. Soil $\mathrm{OC}(\mathrm{OC})$ content was determined by the modified WalkleyBlack method (USDA, 2004). Soil acidity $(\mathrm{pH})$ was measured in aqueous soil extracted in de-ionised water (1:2.5 soil : water). Total nitrogen was measured by the Regular Macro-Kjeldahl method and $\mathrm{C} / \mathrm{N}$ ratio was calculated.

For texture analysis, air-dried soil subsamples were pre-treated with $\mathrm{H}_{2} \mathrm{O}_{2}(6 \%)$ to remove organic matter and soluble salts, dried in the oven to obtain the initial weight, dispersed with a sodium hexametaphosphate solution, and mechanically shaken. The sand fraction $(0.05-2 \mathrm{~mm})$ was removed from the suspension by wet sieving and then fractionated by dry sieving; the fine silt $(0.002-0.02 \mathrm{~mm})$ and clay $(<0.002 \mathrm{~mm})$ frac-
SOILD

$1,295-325,2014$

Organic $\mathbf{C}$ and water repellency

distribution in soil aggregates

A. Jordán et al.

\section{Title Page}

\section{Abstract}

Conclusions

Tables

References

\section{Figures}

\section{4}

4

Back

Printer-friendly Version

Interactive Discussion 
was calculated as the difference between $100 \%$ and the sum of the sand, clay, and fine silt percentages.

The intensity of WR was assessed using the ethanol percentage test (EPT). Drops $(0.5 \mu \mathrm{L})$ of decreasing ethanol concentrations (increasing surface tensions) were ap5 plied onto the soil surface with a micro-pipet until one of the drops balled out in the first 5 seconds after application. This allows the classification of the soil into a surface tension category between two ethanol concentrations. EPT classes were classified as in Doerr (1998): (1) very wettable (0.0 \% ethanol), (2) wettable (3.0\%), (3) slightly water repellent $(5.0 \%),(4)$ moderately water repellent $(8.5 \%),(5)$ strongly water repellent $10 \quad(13.0 \%),(6)$ very strongly water repellent $(24.0 \%)$ and (7) extremely water repellent (36.0\%).

In order to study the relation between stability to slaking, WR and OC, 90 air-dried aggregates (about $10 \mathrm{~mm}$ in size) selected per treatment (mulched or conventional tillage) and crop (apricot, citrus and wheat). Every set of aggregates was randomly divided in 15 three groups $(n=30)$ for assessing stability to slaking, WR and OC, respectively. For analysing stability to slaking, selected aggregates were placed on a $1.5 \mathrm{~mm}$ sieve and immersed in distilled water $(20 \mathrm{~mm}$ depth) during $5 \mathrm{~min}$, and the time for $50 \%$ loss of structural integrity was recorded. If structural integrity of aggregates is maintained after $5 \mathrm{~min}$, immersion was repeated 5 times and the soil material remaining on the sieve 20 was dried and weighted. Stability to slaking was determined according to Herrick et al. (2001) (Table 1).

\subsection{Data analysis}

The normal distribution of data was assessed using the Shapiro-Wilk test. When data fitted the normal distribution, data analysis included basic data descriptions (means 25 and standard deviations, ANOVA). When data did not fit the normal distribution, nonparametric tests were applied (Wilcoxon test for comparison of median values, Spearman rank correlation coefficient). Differences between the intensity of WR in aggregate layers were assessed using the Kruskal-Wallis and the median Mood's test, and it was
SOILD

$1,295-325,2014$

Organic $\mathbf{C}$ and water repellency

distribution in soil aggregates

A. Jordán et al.

\section{Title Page}

Abstract Introduction

Conclusions References

Tables Figures

14 $>$ I

4

Back

Full Screen / Esc

Printer-friendly Version

Interactive Discussion 
considered that significant differences existed when confirmed at least by one of these tests. All computations and graphical displays were performed using SPSS (IBM Corp., 2013).

\section{Results}

\section{$5 \quad 3.1$ Characterization of studied soils}

The results of soil characterization $(0-10 \mathrm{~cm})$ is shown in Table 2. Studied soils are neutral ( $\mathrm{pH} 7.1 \pm 0.1$, on average), with OC content varying between 1.35 and $1.55 \%$ (conventional tillage) and 4.60 and 5.25 (mulched soils). Soil texture varied between silt loam and silty clay loam, with average sand and clay contents $9.7 \pm 1.6$ and $24.6 \pm 2.6 \%$, 10 respectively.

\subsection{Organic $\mathrm{C}$ content and water repellency in aggregate size fractions}

Soil OC content from aggregate size fractions showed significant differences according to crop, treatment and size (Table 3). On average, OC content varied between $1.50 \pm 0.88$ (wheat) and $2.00 \pm 0.93 \%$ (apricot). Mulching increased OC content from $151.00 \pm 0.35$ (conventional tillage) to $2.49 \pm 0.57 \%$ (mulched soils). OC content varied with size, with maximum value between $1.91 \pm 0.90$ and $2.20 \pm 1.105$ (size fractions $0.5-1$ and $0.25-0.5 \mathrm{~mm}$, respectively).

Figure 2 shows the distribution of $\mathrm{OC}$ content from soils under different crop and treatment per size fractions. The distribution of $\mathrm{OC}$ content from different crops under conventional tillage did not show any particular behaviour, with values ranging between $0.62 \pm 0.25$ (wheat, $5-10 \mathrm{~mm}$ ) and $1.41 \pm 0.23 \%$ (apricot, $0.25-0.5 \mathrm{~mm}$ ), on average. In contrast, OC content decreased whit increasing size in mulched soils under all crops. In this case, OC content varied between $2.44 \pm 0.11(5-10 \mathrm{~mm})$ and $3.46 \pm 0.22 \%(0.25-$ $0.5 \mathrm{~mm})$ under apricot, $2.11 \pm 0.2(10-15 \mathrm{~mm})$ and $3.28 \pm 0.61 \%(0.25-0.5 \mathrm{~mm})$ under citrus and $1.62 \pm 0.44(10-15 \mathrm{~mm})$ and $2.85 \pm 0.29 \%(0.25-0.5 \mathrm{~mm})$ under wheat.

\section{SOILD}

$1,295-325,2014$

Organic $\mathbf{C}$ and water repellency

distribution in soil aggregates

A. Jordán et al.

Title Page

Abstract Introduction

Conclusions References

Tables Figures



Full Screen / Esc

Printer-friendly Version

Interactive Discussion 
The intensity of WR did not show significant differences among crops, but varied significantly per treatment and size fraction (Table 4). Figure 3 shows the distribution of EPT values from soils under different crop and treatment per size fractions. The intensity of soil WR decreased with increasing size under all crops and treatments. 5 Median EPT values generally varied between 2 (fractions between 2 and $15 \mathrm{~mm}$ ) and 3 (fractions between 0.25 and $2 \mathrm{~mm}$ ), shifting from slightly water repellent to wettable between size fractions 1-2 and 2-5 mm. In contrast, median EPT values from mulched soils under wheat were $2(10-15 \mathrm{~mm}), 4(1-2,2-5$ and $5-12)$ and $5(0.25-0.5$ and 0.5-1 mm).

\subsection{Intra-aggregate distribution of organic C}

The distribution of $\mathrm{OC}$ content from aggregate layers varied with soil treatment. Table 5 shows the results of the ANOVA for OC content of soil samples from each crop and treatment for different aggregate layers. On average, $\mathrm{OC}$ content in aggregate layers from conventionally tilled soils varied between $0.34 \pm 0.13$ (interior layer of ag15 gregates from conventionally tilled soils under citrus) and $2.97 \pm 0.52 \%$ (transitional layer of aggregates from mulched soils under apricot). In aggregates from soils under conventional tillage, the distribution of $\mathrm{OC}$ content decreased strongly between the exterior and interior layers. In citrus cropped conventionally tilled soils, for example, OC content decreased by $30.10 \%$. In contrast, mulched soils did not show intra-aggregate 20 variations, with average $\mathrm{OC}$ contents of $2.93 \pm 0.50$ (apricot), $2.75 \pm 0.69$ (citrus) and $2.27 \pm 0.61 \%$ (wheat).

\subsection{Intra-aggregate distribution of water repellency}

In general, the intensity of soil WR from aggregate layers of soil samples under different crops and treatments varied between EPT $=1$ (very wettable) and 4 (moderately water repellent). The range of EPT values was 1-3 (median 2-2.5) in conventionally tilled soils) and 1-4 (median 2-3) in mulched soils. Table 6 shows the results
SOILD

1, 295-325, 2014

Organic $\mathbf{C}$ and water repellency

distribution in soil aggregates

A. Jordán et al.

\section{Title Page}

Abstract Introduction

Conclusions References

Tables Figures

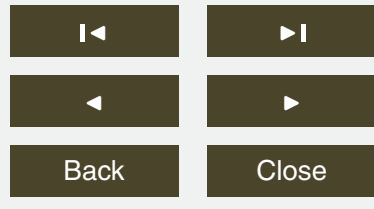

Full Screen / Esc

Printer-friendly Version

Interactive Discussion 
of the Kruskal-Wallis and Mood's median tests. Results show that significant differences among EPT median values from different layers were found only in aggregates from conventionally tilled soils under wheat and mulched soils under apricot. In the first case, median EPT varied between 2 (interior and transitional layers) and 2.5 (exterior 5 layer). Although this difference is considered significant, it only implies a jump between wettable and wettable to slightly water-repellent classes and has not any hydrological meaning.

\subsection{Slaking stability and relation with water repellency and organic $\mathrm{C}$ content}

Median values of stability to slaking determined in aggregates $(\sim 10 \mathrm{~mm})$ from soil samples under different crops and treatments are shown in Table 7. Stability to slaking varied between crops and treatments. Median slaking values varied between 3 (apricot and citrus) and 4 (wheat) in conventionally tilled soils and between 4 (apricot and citrus) and 5 (wheat) in mulched soils. In all cases, stability to slaking in mulched soils was 1 unit greater than in conventionally tilled soils.

15 Table 8 shows the R-Spearman coefficients for slaking/EPT, slaking/OC content and EPT/OC content. When all cases are considered together, stability to slaking was significantly correlated with EPT $(\mathrm{R}-\mathrm{Spearman}=0.8699)$. Significant positive correlations were found between stability to slaking and EPT in all cases, except for aggregates under wheat and conventional tillage. No significant correlations were found between stability to slaking and OC content or WR and OC content in aggregates under different crops and treatments, except when all cases were considered together $(0.5245$ and 0.4317 , respectively).
SOILD

$1,295-325,2014$

Organic $\mathbf{C}$ and water repellency

distribution in soil aggregates

A. Jordán et al.

\section{Title Page}

Abstract Introduction

Conclusions References

Tables Figures

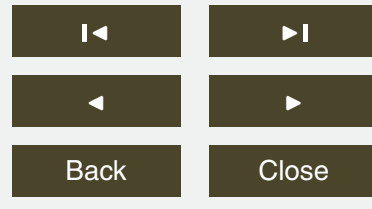

Full Screen / Esc

Printer-friendly Version

Interactive Discussion 


\section{Discussion}

\subsection{Distribution of organic $C$ by aggregate size}

Although soil $\mathrm{OC}$ content in the fine earth $(<2 \mathrm{~mm})$ did not vary among crops, no-tilling and mulching treatments contributed to increase it largely (approximately by 3.4 , on average) versus conventional tilling, as shown by previous research (Jordán et al., 2010). In contrast, the $\mathrm{OC}$ content of size fractions varied significantly among soils under apricot, citrus and wheat crops, independently of other factors. Generally, OC content was higher in the finer aggregates $(0.25-0.5$ and $0.5-1 \mathrm{~mm})$, what is in agreement with previous research (Bisdom et al., 1993; Covaleda et al., 2011; Puget et al., 1995). Urbanek et al. (2007) observed that aggregates released by fragmenting following the plane of weakness show higher organic matter content with decreasing aggregate size. They explained this partly because of sampling disturbance. In our experiment, undisturbed soil aggregates were carefully handled and selected by size individually, not sieved in order to avoid disturbance as much as possible. Although the $\mathrm{C}$ content generally decreased with increasing aggregate size, this trend was much more intense in mulched soils. This is in contrast with results reported by Urbanek et al. (2007), who found that OC did not increased with decreasing aggregate size under conservation tillage. They observed that differences in treatment of samples may be the cause of different results, as a large amount of OC weakly associated to macroaggregates may be easily removed during mechanical disturbance (Urbanek et al., 2007). In addition, low organic matter inputs and high mineralization rates in conventionally tilled soils may lead to low $\mathrm{OC}$ concentrations independently of the size of aggregates and negligible differences.

\subsection{Distribution of organic $\mathrm{C}$ by aggregate region}

The intra-aggregate distribution of $\mathrm{OC}$ varied in conventionally tilled soils, decreasing from the exterior to the interior layer. Contradictory results have been reported in previous research. Amelung and Zech (1996), Fan et al. (2013), Santos et al. (1997) and
SOILD

$1,295-325,2014$

Organic $\mathrm{C}$ and water repellency

distribution in soil aggregates

A. Jordán et al.

\section{Title Page}

14

Back

Printer-friendly Version

Interactive Discussion 
Urbanek et al. (2007) did not found gradients in the distribution of OC among the exterior and the interior regions of aggregates, but other authors have found conflicting results. Park and Smucker (2005), for example, found significant differences between the exterior and interior regions of aggregates from conventionally tilled silt loam soils, 5 but not in other similar cases they studied. Ellerbrock and Gerke (2004) observed that, in arable soils, organic matter content in the exterior layer of aggregates was greater than in the interior with differences increasing with depth. Although bacteria and fungi cannot penetrate the interior layers of aggregates, leading to retarded mineralization of organic substances (Jasinska et al., 2006) in this region, Amelung and Zech (1996) 10 suggested that continuous tillage contributes to losses of OC physically protected in the interior of aggregates and that preferential loss from aggregate surfaces is caused generally by accelerated decay. Our results suggest that higher OC concentration in the exterior layer of aggregates may be due to recent residue inputs or leachates from the surface and high mineralization rates in cultivated soils should help to make differences decrease in the medium- or long- term. This is in agreement with Ellerbrock and Gerke (2004) who described that new organic inputs are incorporated preferably in the exterior layer.

Our results also show that the intra-aggregate distribution of OC from mulched does not vary significantly. In native soils, where organic matter inputs are generally higher, researchers have reported increased OC concentration in the interior layer of forest soils (Fan et al., 2013; Jasinska et al., 2006) or homogenous OC concentrations in different regions of aggregates from forest soils (Park and Smucker, 2005) and prairie soils (Amelung and Zech, 1996). These results are similar to those observed in no-tilled soils by Park and Smucker (2005). Our findings suggest that higher inputs of organic residues result in higher $\mathrm{OC}$ content but not always in a heterogeneous intra-aggregate distribution.

SOILD

$1,295-325,2014$

Organic $\mathbf{C}$ and water repellency

distribution in soil aggregates

A. Jordán et al.

\section{Title Page}

Abstract Introduction

Conclusions References

Tables Figures

14 $>$ I

4

Back

Full Screen / Esc

Printer-friendly Version

Interactive Discussion 


\subsection{Relation between water repellency and treatment}

The intensity of WR did not vary significantly among size fractions of soils under apricot, citrus and wheat crops, independently of other factors. Although variation of soil WR has been reported in soils under natural vegetation (Jordán et al., 2008; Jordán et 5 al., 2009; Martínez-Zavala and Jordán-López, 2009; Mataix-Solera et al., 2007; Schnabel et al., 2013; Zavala et al., 2014), the occurrence of WR is not common in tilled soils (Doerr et al., 2006; Woche et al., 2005). Our findings show that the intensity of soil WR increased from conventionally tilled to untilled mulched soil. This is in agreement with previous research, which has shown that conservative practices contribute 10 to enhanced WR in cultivated soils (Blanco-Canqui and Lal, 2009; García-Moreno et al., 2013; González-Peñaloza et al., 2012; Simon et al., 2009).

\subsection{Distribution of water repellency by aggregate size}

Higher OC concentration in finer aggregates conditioned the distribution of WR. This is in agreement with previous research in forest soils (Doerr et al., 1996; Jordán et al., 15 2011; Jordán et al., 2014; Mataix-Solera and Doerr, 2004; Mataix-Solera et al., 2014). In conventionally tilled soils, where differences in OC content among aggregates with different size where small, the intensity of WR only increased from wettable (coarser aggregates) to slight (finer aggregates). In contrast, it varied between moderate/strong (finer aggregates) and slight/wettable (coarser aggregates) in mulched soils. Greater 20 differences observed in aggregates with different size from mulched soils are in agreement with differences in the distribution of OC.

\subsection{Distribution of water repellency by aggregate region}

Although many authors have found correlations between OC content and persistence or intensity of WR in soils (Mataix-Solera and Doerr, 2004; Mataix-Solera et al., 2014), small or non-significant differences were observed in the intensity of WR from aggregate

\section{SOILD}

$1,295-325,2014$

Organic $\mathbf{C}$ and water repellency

distribution in soil aggregates

A. Jordán et al.

Title Page

Abstract

Conclusions

Tables

\section{Figures}

14

4

Back

Full Screen / Esc

Printer-friendly Version

Interactive Discussion 
regions. According to Bisdom et al. (1993), WR is closely related with organic matter content. They observed that organic hydrophobic structures causing WR are relatively intact plant residues (remnants of roots, leaves and stems) and transformed organic matter coating mineral particles and aggregates or present in the soil matrix as inter5 stitial materials. Significant differences were only found in mulched soils under citrus and conventionally tilled soils under apricot. Nevertheless, in both cases, these differences did not mean a qualitative jump between classes of WR (which were only from wettable to slightly water-repellent at best). Consequently, it can be assumed that mulching increased soil WR, but did not condition the distribution of hydrophobicity at 10 the intra-aggregate level. In contrast to Urbanek et al. (2007), in our case, differences in chemical characteristics of organic matter, if existing, are not responsible of the intraaggregate distribution of WR.

\subsection{Slaking stability}

Soil WR enhances aggregate stability to slaking. In contact with water, air bubbles 15 entrapped in soil pores and differential swelling may cause tensions and destruction of aggregates (Chan and Mullins, 1994). Consequently, retarded wetting caused by WR may enhance aggregate stability to slaking. High positive significant correlations were observed between slaking stability and the intensity of WR in most cases. In contrast, poor (only when all cases were computed together) or non-significant correlations were found between slaking stability and OC. Although soil WR was generally correlated with slaking stability (only conventionally tilled soils under wheat showed no correlation), greater Spearman's correlation coefficients were observed in mulched soils. The intensity of WR seems to be the main responsible of slaking stability, as differences in OC content between conventionally tilled (1.35-1.55\%) and mulched soils

\section{SOILD}

$1,295-325,2014$

Organic $\mathbf{C}$ and water repellency

distribution in soil aggregates

A. Jordán et al.

Title Page

Abstract

Conclusions

Tables

Figures

14

4

Back

Printer-friendly Version results reported by different authors (Benito et al., 2003; Chenu et al., 2000; Granged et al., 2011; Hallett et al., 2001b; Piccolo and Mbagwu, 1999; Zavala et al., 2010). According to Mataix-Solera et al. (2011), a direct consequence of retarded water entry in 
water-repellent aggregates is the enhanced aggregate stability, as the energy release rate and build-up of air pressure in pores is reduced.

\subsection{General implications of results}

Evidence of more intense WR on the surface of smaller aggregates is in contrast with 5 the results observed by Peng et al. (2003), who found a trend of increased repellency with increasing aggregate size in severely degraded soils, apparently due to the eluviation of organic compounds and greater microbial activity in macropores. Our results show an opposite trend in agricultural soils, with more intense WR in finer aggregates (mostly below $2 \mathrm{~mm}$ ), and this trend is even more pronounced in mulched soils, with higher organic matter inputs. This is in agreement with increased organic matter concentration in finer aggregates, as observed in conventinally tilled and mulched soils. Hydrophobic microbial exudates are produced mainly in the surface of macroaggregates in contact with macopores. Consequently, it may be suggested that hydrophobic compounds are leached from coarser to finer aggregates, where biological activity is gates and water infiltration is more efficient, more intense WR in the surface of finer aggregates may limit infiltration rates. Inhibited infiltration caused by water-repellent fine aggregates may contribute to increased runoff rates, what has been previously observed at high organic matter input rates (González-Peñaloza et al., 2012; Jordán et al., 2010). Consequently, more research is required to determine the effect of WR incudec by low or moderate mulching rates in runoff generation, water dynamics and possible implications for nutrient transport or water retention in the root zone.

Our results show that subcritical to moderate WR and increased OC concentration contribute to stability of aggregates in mulched soils. On one hand, WR contributes to

decreased slaking stress by reducing the energy release rate caused by entrapped air bubbles during wetting, and, on the other hand, organic substances increase bonding strength between mineral soil particles. Several authors (Czarnes et al., 2000; Hallet et al., 2001a; Mataix-Solera and Doerr, 2004; Mataix-Solera et al., 2011; Piccolo and
SOILD

1, 295-325, 2014

Organic $\mathbf{C}$ and water repellency

distribution in soil aggregates

A. Jordán et al.

Title Page

Abstract Introduction

Conclusions References

Tables Figures

14 $>$ I

4

Back

Full Screen / Esc

Printer-friendly Version

Interactive Discussion 
Mbagwu, 1999) have highlighted the combined role of organic cementing substances and hydrophobic compounds in increasing the stability of soil aggregates. This is especially relevant for agricultural soils, as increased aggregate stability leads to infiltration through macropores, so reducing erosion risk and surface sealing, as shown by Peng 5 et al. (2003).

\section{Conclusions}

The OC content varied in function of soil use, treatments and aggregate size. In general, mulching contributed to enhance soil WR in cropped soils under apricot, citrus and wheat. The OC content varied between aggregates of different size, generally decreasing with increasing diameter. This trend was more intense in mulched than in conventionally tilled soils.

The distribution of $\mathrm{OC}$ content in aggregates from mulched soils was homogeneous. Aggregates from conventionally tilled soils showed lower contents, but irregularly distributed, with larger concentrations in the exterior layer of aggregates. This gradient 15 may be caused by recent organic matter inputs.

The intensity of WR (assessed by the EPT) increased with mulching and decreasing aggregate size. Higher intensities of WR found in finer aggregates may be caused by higher OC concentrations, especially in mulched soils. Small or no differences were found among aggregate layers from soils under different uses and treatments. Although 20

OC content did not show any influence in aggregate stability to slaking, the intensity of WR contributed to enhanced stability, especially in mulched soils under all crops considered.

Further research is required to study the impact of these results on runoff generation, soil erosion risk and water dynamics and associated nutrient transport in soils 25 vative management of agricultural soils. Future studies should also consider the effect

SOILD

$1,295-325,2014$

Organic $\mathbf{C}$ and water repellency

distribution in soil aggregates

A. Jordán et al.

\section{Title Page}

Abstract Introduction

Conclusions References

Tables Figures

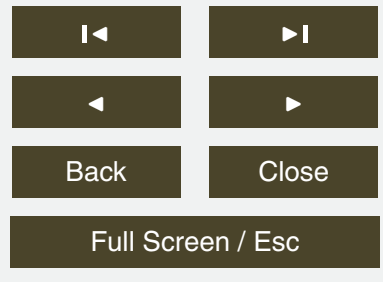

Printer-friendly Version

Interactive Discussion 
of the redistribution of hydrophobic substances between and within micro-and macroaggregates, as well as physical, chemical and biological processes involved.

Acknowledgements. Alfonso Mazuelos (Dept. of Chemical Engineering, University of Seville) allowed us to use his laboratory and kindly offered his generous assistance in some of the 5 experiments. The authors are also thankful to Antonio Jordán senior, who helped with the design and making of micro-sieves for the slaking test and Luis F. Pérez (IFAPA Las TorresTomejil).

This study has been funded by Spanish Ministry of Economy and Competitiveness through the research projects "HYDFIRE: Water repellency in Mediterranean fire-affected soils. In10 volved factors, temporal changes and implications for hydrology and soil system functioning" (CGL2010-21670-C02-01) and "GEOFIRE: Geochemical alterations in fire affected soils" (CGL2012-38655-C04-01) and the Andalusian Regional Ministry for Science (2011/RNM-364).

\section{References}

Amelung, W. and Zech, W.: Organic species in ped surface and core fractions along a climosequence in the prairie, North America. Geoderma, 74, 193-206, 1996.

Benito, E., Santiago, J. L., de Blas, E., and Varela, M. E.: Deforestation of water-repellent soils in Galicia (NW Spain): effects on surface runoff and erosion under simulated rainfall, Earth Surf. Process. Landf., 28, 145-155, 2003.

Bisdom, E. B. A., Dekker, L. W., and Schoute, J. F. Th.: Water repellency of sieve fractions from sandy soils and relationships with organic material and soil structure, Geoderma, 56, 105-118, 1993.

Blanco-Canqui, $\mathrm{H}$. and Lal, R.: Extent of soil water repellency under long-term no-till soils, Geoderma, 149, 171-180, 2009.

Bodí, M. B., Muñoz-Santa, I., Armero, C., Doerr, S. H., Mataix-Solera, J., and Cerdà, A.: Spatial and temporal variations of water repellency and probability of its occurrence in calcareous Mediterranean rangeland soils affected by fires, Catena, 108, 14-25, 2013.

Buczko, U., Bens, O., and Hüttl, R. F.: Tillage Effects on Hydraulic Properties and Macroporosity in Silty and Sandy Soils, Soil Sci. Soc. Am. J., 70, 1998-2007, 2006.

Chan, K. Y. and Mullins, C. E.: Slaking characteristics of some Australian and British soils, Euro. J. Soil Sci., 45, 273-283, 1994.
SOILD

$1,295-325,2014$

\section{Organic $\mathbf{C}$ and water repellency \\ distribution in soil aggregates}

A. Jordán et al.

Title Page

Abstract Introduction

Conclusions References

Tables Figures

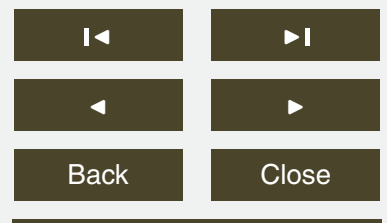

Full Screen / Esc

Printer-friendly Version

Interactive Discussion 
Chenu, C., Le Bissonnais, Y., and Arrouays, D.: Organic matter influence on clay wettability and soil aggregate stability, Soil Sci. Soc. Am. J., 64, 1479-1486, 2000.

Covaleda, S., Gallardo, J. F., García-Oliva, F., Kirchmann, H., Prat, C., Bravo, M., and Etchevers, J. D.: Land-use effects on the distribution of soil OC within particle-size fractions of volcanic soils in the Transmexican Volcanic Belt (Mexico), Soil Use Manage., 27, 186-194, 2011.

Czarnes, S., Hallet, P. D., Bengough, A. G., and Young, I. M.: Root- and microbial-derived mucilages affect soil structure and water transport, Euro. J. Soil Sci., 51, 435-443, 2000.

DeBano, L. F.: Water repellency in soils: a historical overview, J. Hydrol., 231-232, 4-32, 2000.

Dexter, A. R.: Advances in characterization of soil structure, Soil Till. Res., 11, 199-288, 1988.

10 Doerr, S. H.: On standardising the "Water Drop Penetration Time" and the "Molarity of an Ethanol Droplet" techniques to classify soil water repellency: a case study using medium textured soils, Earth Surf. Process. Landf., 23, 663-668, 1998.

Doerr, S. H., Shakesby, R. A., and Walsh, R. P. D.: Soil hydrophobicity variations with depth and particle size fraction in burned and unburned Eucalyptus globulus and Pinus pinaster forest terrain in the Águeda Basin, Portugal, Catena, 27, 25-47, 1996.

Doerr, S. H., Shakesby, R. A., and Walsh, R. P. D.: Soil water repellency: its causes, characteristics and hydro-geomorphological significance, Earth-Sci. Rev., 51, 33-65, 2000.

Ellerbrock, R. H. and Gerke, H. H.: Characterizing organic matter of soil aggregate coatings and biopores by Fourier transform infrared spectroscopy, Euro. J. Soil Sci., 55, 219-228, 2004.

Fan, R., Yang, X., Drury, C. F., Guo, X., and Zhang, X.: Distribution and stability of OC in soil aggregate external and internal layers under three different land-use systems, Soil Sci. Soc. Am. J., 77, 1625-1635, 2013.

García-Moreno, J., Gordillo-Rivero, A. J., Zavala, L. M., Jordán, A., and Pereira, P.: Mulch application in fruit orchards increases the persistence of soil water repellency during a 15-years period, Soil Till. Res., 130, 62-68, 2013.

Goebel, M.-O., Bachmann, J., Woche, S. K., and Fischer, W. R.: Soil wettability, aggregate stability, and the decomposition of soil organic matter, Geoderma, 128, 80-93, 2005.

González-Peñaloza, F. A., Cerdà, A., Zavala, L. M., Jordán, A., Giménez-Morera, A., Arcenegui, 30 V., and Ruiz-Gallardo, J. R.: Do conservative agriculture practices increase soil water repellency? A case study in citrus-cropped soils, Soil Till. Res., 214, 233-239, 2012.
SOILD

1, 295-325, 2014

\section{Organic $\mathbf{C}$ and water repellency \\ distribution in soil aggregates}

A. Jordán et al.

\section{Title Page}

\section{Abstract}

Introduction

Conclusions

References

Tables

Figures

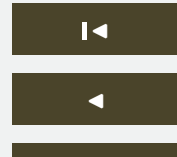

$>$ I

Back

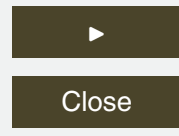

Full Screen / Esc

Printer-friendly Version

Interactive Discussion 
Granged, A. J. P., Zavala, L. M., Jordán, A., and Bárcenas-Moreno, G.: Post-fire evolution of soil properties and vegetation cover in a Mediterranean heathland after experimental burning: A 3-year study, Geoderma, 164, 85-94, 2011.

Hallett, P. D., Baumgartl, T., and Young, I. M.: Subcritical water repellency of aggregates from a range of soil management practices, Soil Sci. Soc. Am. J., 65, 184-190, 2001a.

Hallett, P. D., Ritz, K., and Wheatley, R. E.: Microbial derived water repellency in soil, Int. Turfgrass Soc. Res. J., 9, 518-524, 2001b.

Herrick, J. E., Whitford, W. G., de Soyza, A. G., Van Zee, J. W., Havstad, K. M., Seybold, C. A., and Walton, M.: Field soil aggregate stability kit for soil quality and rangeland health 10 evaluations, Catena, 44, 27-35, 2001.

Horn, R.: Aggregate characterization as compared to soil bulk properties, Soil Till. Res., 17, 265-289, 1990.

Horn, R., Taubner, H., Wuttke, M., and Baumgartl, T.: Soil physical properties and processes related to soil structure, Soil Till. Res., 30, 187-216, 1994.

15 IBM Corp.: IBM SPSS Statistics for Windows, Version 22.0, IBM Corp. Armonk, NY, 2013.

Jasinska, E., Wetzel, H., Baumgartl, T., and Horn, R.: Heterogeneity of physic-chemical properties in structured soils and its consequences, Pedosphere, 16, 284-296, 2006.

Jordán, A., Martínez-Zavala, L., and Bellinfante, N.: Heterogeneity in soil hydrological response from different land cover types in southern Spain, Catena, 74, 137-143, 2008.

20

Jordán, A., Zavala, L. M., Nava, A. L., and Alanís, N.: Occurrence and hydrological effects of water repellency in different soil and land use types in Mexican volcanic highlands, Catena, 79, 60-71, 2009.

Jordán, A., Zavala, L. M., and Gil, J.: Effects of mulching on soil physical properties and runoff under semi-arid conditions in southern Spain, Catena, 81, 77-85, 2010.

Jordán, A., Zavala, L. M., Mataix-Solera, J., Nava, A. L., and Alanís, N.: Effect of fire severity on water repellency and aggregate stability on Mexican volcanic soils, Catena, 84, 136-147, 2011.

Jordán, A., Zavala, L. M., Mataix-Solera, J., and Doerr, S. H.: Soil water repellency: Origin, assessment and geomorphological consequences, Catena, 108, 1-5, 2013.

30 Jordán, A., Gordillo-Rivero, A. J., García-Moreno, J., Zavala, L. M., Granged, A. J. P., Gil, J., and Neto-Paixão, H. M.: Post-fire evolution of water repellency and aggregate stability in Mediterranean calcareous soils: A 6-year study, Catena, 118, 115-123, 2014.
SOILD

1, 295-325, 2014

Organic $\mathbf{C}$ and water repellency

distribution in soil aggregates

A. Jordán et al.

Title Page

Abstract Introduction

Conclusions References

Tables Figures

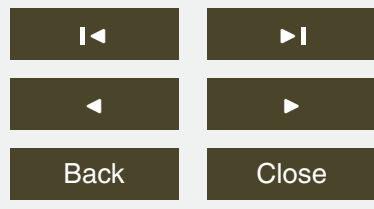

Full Screen / Esc

Printer-friendly Version

Interactive Discussion 
Lozano, E., Jiménez-Pinilla. P., Mataix-Solera, J., Arcenegui, V., Bárcenas, G. M., GonzálezPérez, J. A., García-Orenes, F., Torres, M. P., and Mataix-Beneyto, J.: Biological and chemical factors controlling the patchy distribution of soil water repellency among plant species in a Mediterranean semiarid forest, Geoderma, 207-208, 212-220, 2013.

5 Martínez-Zavala, L. and Jordán-López, A.: Influence of different plant species on water repellency in Mediterranean heathland soils, Catena, 76, 215-223, 2009.

Mataix-Solera, J. and Doerr, S. H.: Hydrophobicity and aggregate stability in calcareous topsoils from fire-affected pine forests in southeastern Spain, Geoderma, 118, 77-88, 2004.

Mataix-Solera, J., Arcenegui, V., Guerrero, C., Mayoral, A. M., Morales, J., González, J., GarcíaOrenes, F., and Gómez, I.: Water repellency under different plant species in a calcareous forest soil in a semiarid Mediterranean environment, J. Hydrol., 21, 2300-2309, 2007.

Mataix-Solera, J., Cerdà, A., Arcenegui, V., Jordán, A., and Zavala, L. M.: Fire effects on soil aggregation: a review, Earth-Sci. Rev., 109, 44-60, 2011.

Mataix-Solera, J., Arcenegui, V., Zavala, L. M., Pérez-Bejarano, A., Jordán, A., Morugán15 Coronado, A., Bárcenas-Moreno, G., Jiménez-Pinilla, P., Lozano, E., Granged, A. J. P., and Gil, J.: Small variations of soil properties control fire-induced water repellency, Spanish J. Soil Sci., 4, 51-60, 2014.

Park, E.-J. and Smucker, A. J. M.: Erosive strengths of concentric regions within soil macroaggregates, Soil Sci. Soc. Am. J., 69, 1912-1921, 2005.

20 Peng, X., Zhang, B., Zhao, Q., Horn, R., and Hallet, P.D.: Influence of types of restorative vegetation on the wetting properties of aggregates in a severely degraded clayey Ultisol in subtropical China, Geoderma, 115, 313-324, 2003.

Piccolo, A. and Mbagwu, J. S. C.: Role of hydrophobic components of soil organic matter in soil aggregate stability, Soil Sci. Soc. Am. J., 63, 1801-1810, 1999.

Santos, D., Murphy, S. L. S., Taubner, H., Smucker, A. J. M., and Horn, R.: Uniform separation of concentric surface layers from soil aggregates, Soil Sci. Soc. Am. J., 61, 720-724, 1997.

Schnabel, S., Pulido-Fernández, M., and Lavado-Contador, J. F.: Soil water repellency in rangelands of Extremadura (Spain) and its relationship with land management, Catena, 103, 5361, 2013.

so Simon, T., Javurek, M., Mikanova, O., and Vach, M.: The influence of tillage systems on soil organic matter and soil hydrophobicity, Soil Till. Res., 105, 44-48, 2009.
SOILD

$1,295-325,2014$

\section{Organic $\mathbf{C}$ and water repellency \\ distribution in soil aggregates}

A. Jordán et al.

Title Page

Abstract

Introduction

Conclusions References

Tables

Figures

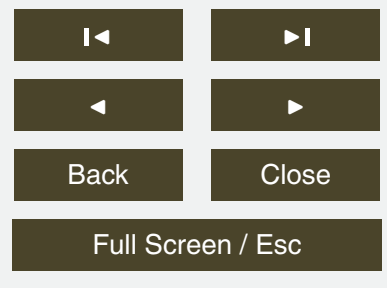

Printer-friendly Version

Interactive Discussion 
Urbanek, E., Hallett, P., Feeney, D., and Horn, R.: Water repellency and distribution of hydrophilic and hydrophobic compounds in soil aggregates from different tillage systems, Geoderma, 140, 147-155, 2007.

USDA: Soil survey laboratory methods manual. Soil survey investigation report No. 42. Version 4.0. US Department of Agriculture-NCRS: Lincoln, NE, 2004.

WRB: World reference base for soil resources 2006, 2nd Edn., World Soil Resources Reports No 103, Food and Agriculture Organization of the United Nations, Rome, 2006.

Zavala, L. M., Granged, A. J. P., Jordán, A., and Bárcenas-Moreno, G.: Effect of burning temperature on water repellency and aggregate stability in forest soils under laboratory conditions,

10 Geoderma, 158, 36-374, 2010.

Zavala, L. M., García-Moreno, J., Gordillo-Rivero, A. J., Jordán, A., and Mataix-Solera, J.: Natural soil water repellency in different types of Mediterranean woodlands, Geoderma, 227-227, 170-178, 2014.

\section{SOILD}

1, 295-325, 2014

\section{Organic $\mathbf{C}$ and water repellency \\ distribution in soil aggregates}

A. Jordán et al.

Title Page

Abstract

Introduction

Conclusions

References

Tables

Figures

14

$\rightarrow 1$

Back

Close

Full Screen / Esc

Printer-friendly Version

Interactive Discussion 


\section{SOILD}

1, 295-325, 2014

\section{Organic $\mathbf{C}$ and water repellency \\ distribution in soil aggregates}

Table 1. Criteria for classification of stability to slaking (Herrick et al., 2001).

\section{Slaking Criteria for each slaking class}

class

$050 \%$ of structural integrity is lost immediately after immersion.

$150 \%$ of structural integrity is lost $5 \mathrm{~s}$ after immersion.

$250 \%$ of structural integrity is lost 5-30 s after immersion.

$350 \%$ of structural integrity is lost $30-300$ s after immersion or $<10 \%$ of soil material remains on the sieve after 5 immersion cycles.

$4 \quad 10-25 \%$ of soil material remains on the sieve after 5 immersion cycles.

$525-75 \%$ of soil material remains on the sieve after 5 immersion cycles.

$6>75 \%$ of soil material remains on the sieve after 5 immersion cycles.
A. Jordán et al.

\section{Title Page}

Abstract

Introduction

Conclusions

References

Tables

Figures

14

4

Back

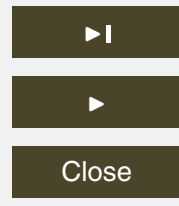

Full Screen / Esc

Printer-friendly Version

Interactive Discussion 


\section{SOILD}

$1,295-325,2014$

Organic $\mathbf{C}$ and water repellency

distribution in soil aggregates

A. Jordán et al.

Table 2. Characterization of studied soils in the $0-10 \mathrm{~cm}$ layer. SD: standard deviation.

\begin{tabular}{llrrrrr}
\hline Crop & Treatment & $\mathrm{pH}$ & Organic C (\%) & Sand (\%) & Silt (\%) & Clay (\%) \\
\hline Apricot & Conventional tillage & 7.0 & 1.55 & 7.4 & 69.4 & 23.2 \\
Apricot & Mulch & 7.1 & 4.60 & 10.2 & 66.7 & 23.1 \\
Citrus & Conventional tillage & 6.9 & 1.40 & 11.2 & 60.6 & 28.2 \\
Citrus & Mulch & 7.1 & 5.25 & 11.7 & 65.4 & 22.9 \\
Wheat & Conventional tillage & 7.2 & 1.35 & 8.7 & 63.7 & 27.6 \\
Wheat & Mulch & 7.2 & 4.85 & 8.9 & 68.6 & 22.5 \\
Mean \pm SD & & $7.1 \pm 0.1$ & $3.2 \pm 1.9$ & $9.7 \pm 1.6$ & $65.7 \pm 3.3$ & $24.6 \pm 2.6$ \\
\hline
\end{tabular}

Title Page

Abstract

Introduction

Conclusions

References

Tables

Figures

14

4

Back

Full Screen / Esc

Printer-friendly Version

Interactive Discussion 


\section{SOILD}

$1,295-325,2014$

Organic $\mathbf{C}$ and water repellency

Table 3. Results of the ANOVA for organic $C$ content by factors crop, treatment and size fraction. At each group, mean values followed by the same letter did not show significant differences.

\begin{tabular}{lllll}
\hline Factor & Group & $N$ & Mean \pm standard deviation & ANOVA, $p$ value \\
\hline Crop & Apricot & 60 & $2.00 \pm 0.93 \mathrm{~b}$ & 0.0062 \\
& Citrus & 60 & $1.74 \pm 0.89 \mathrm{ab}$ & \\
& Wheat & 60 & $1.50 \pm 0.88 \mathrm{a}$ & 0.0000 \\
\hline Treatment & Conventional tillage & 90 & $1.00 \pm 0.35$ & \\
& Mulch & 90 & $2.49 \pm 0.57$ & 0.0159 \\
\hline Size fraction & $0.25-0.5 \mathrm{~mm}$ & 30 & $2.20 \pm 1.10 \mathrm{~b}$ & \\
& $0.5-1 \mathrm{~mm}$ & 30 & $1.91 \pm 0.90 \mathrm{ab}$ & \\
& $1-2 \mathrm{~mm}$ & 30 & $1.66 \pm 0.77 \mathrm{a}$ & \\
& $10-15 \mathrm{~mm}$ & 30 & $1.42 \pm 0.72 \mathrm{a}$ & \\
& $2-5 \mathrm{~mm}$ & 30 & $1.69 \pm 0.86 \mathrm{a}$ & \\
& $5-10 \mathrm{~mm}$ & 30 & $1.49 \pm 0.76 \mathrm{a}$ & \\
\hline
\end{tabular}

\section{distribution in soil} aggregates

A. Jordán et al.

Title Page

Abstract

Introduction

Conclusions

References

Tables

Figures

14

$>$ I

4

Back

$\checkmark$

Close

Full Screen / Esc

Printer-friendly Version

Interactive Discussion 
Table 4. Results of the Kruskal-Wallis analysis of EPT data by factors crop, treatment and size fraction.

\begin{tabular}{lllllll}
\hline Factor & Group & $N$ & Median & Minimum & Maximum & $\begin{array}{l}\text { Kruskal-Wallis } \\
p \text { value }\end{array}$ \\
\hline Crop & Apricot & 60 & 3 & 2 & 4 & $>0.05$ \\
& Citrus & 60 & 3 & 2 & 4 & \\
& Wheat & 60 & 3 & 2 & 5 & 0.0000 \\
\hline Treatment & Conventional tillage & 90 & 2 & 1 & 3 & \\
& Mulch & 90 & 4 & 2 & 5 & \\
\hline Size fraction & $0.25-0.5 \mathrm{~mm}$ & 30 & 3.5 & 3 & 5 & \\
& $0.5-1 \mathrm{~mm}$ & 30 & 3.5 & 3 & 5 & \\
& $1-2 \mathrm{~mm}$ & 30 & 3 & 2 & 5 & \\
& $10-15 \mathrm{~mm}$ & 30 & 2 & 1 & 3 & \\
& $2-5 \mathrm{~mm}$ & 30 & 2.5 & 2 & 4 & \\
& $5-10 \mathrm{~mm}$ & 30 & 2.5 & 2 & 4 & \\
\hline
\end{tabular}

Organic $\mathbf{C}$ and water repellency

distribution in soil aggregates

A. Jordán et al.

Title Page

Abstract

Introduction

Conclusions

References

Tables

Figures

14

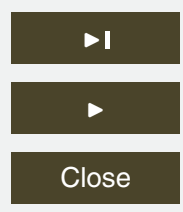

Back

Close

Full Screen / Esc

Printer-friendly Version

Interactive Discussion

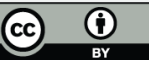


Table 5. Results of the ANOVA for organic C content (OC \%, mean \pm standard deviation) of soil samples from each crop and treatment for different aggregate layers. Mean values followed by different letters showed significant differences for the same use and treatment. $N=30$ for each case.

\begin{tabular}{lllll}
\hline Crop & Treatment & Layer & OC $\%$ & ANOVA, $p$ value \\
\hline Apricot & Conventional tillage & Exterior & $1.25 \pm 0.38 \mathrm{c}$ & $<0.0001$ \\
& & Transitional & $0.94 \pm 0.29 \mathrm{~b}$ & \\
& & Interior & $0.59 \pm 0.20 \mathrm{a}$ & \\
& \multirow{4}{*}{ Mulch } & Exterior & $2.93 \pm 0.49 \mathrm{a}$ & $>0.05$ \\
& & Transitional & $2.97 \pm 0.52 \mathrm{a}$ & \\
& & Interior & $2.88 \pm 0.50 \mathrm{a}$ & \\
\hline Citrus & \multirow{2}{*}{ Conventional tillage } & Exterior & $1.03 \pm 0.35 \mathrm{c}$ & $<0.0001$ \\
& & Transitional & $0.79 \pm 0.29 \mathrm{~b}$ & \\
& \multirow{4}{*}{ Mulch } & Interior & $0.34 \pm 0.13 \mathrm{a}$ & \\
& & Exterior & $2.77 \pm 0.66 \mathrm{a}$ & $>0.05$ \\
& & Transitional & $2.73 \pm 0.72 \mathrm{a}$ & \\
\hline \multirow{2}{*}{ Wheat } & Conventional tillage & Interior & $2.76 \pm 0.73 \mathrm{a}$ & \\
& & Exterior & $0.96 \pm 0.38 \mathrm{c}$ & $<0.0001$ \\
& & Transitional & $0.71 \pm 0.28 \mathrm{~b}$ & \\
& \multirow{2}{*}{ Mulch } & Interior & $0.43 \pm 0.19 \mathrm{a}$ & \\
& & Exterior & $2.28 \pm 0.54 \mathrm{a}$ & $>0.05$ \\
& & Transitional & $2.24 \pm 0.60 \mathrm{a}$ & \\
& & Interior & $2.28 \pm 0.71 \mathrm{a}$ & \\
\hline
\end{tabular}

1, 295-325, 2014

Organic $\mathbf{C}$ and water repellency

distribution in soil aggregates

A. Jordán et al.

Title Page

Abstract

Introduction

Conclusions

References

Tables

Figures

14

$>$ I

4

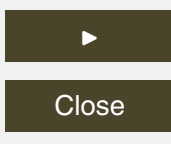

Back

Close

Full Screen / Esc

Printer-friendly Version

Interactive Discussion 
SOILD

$1,295-325,2014$

Table 6. Results of the Kruskal-Wallis (KW, $p$ ) and Mood's median test (Median test, $p$ ) for intensity of soil WR (EPT) of soil samples from each crop and treatment for different aggregate layers (1: exterior; 2 : transitional; 3 : interior). $N=30$ for each case.

\begin{tabular}{|c|c|c|c|c|c|c|}
\hline Crop & Treatment & Layer & EPT & EPT range & $\mathrm{KW}, p$ & Median test, $p$ \\
\hline \multirow[t]{6}{*}{ Apricot } & \multirow[t]{3}{*}{ Conventional tillage } & Exterior & 2 & $(1,3)$ & \multirow[t]{3}{*}{$>0.05$} & \multirow[t]{3}{*}{$>0.05$} \\
\hline & & Transitional & 2 & $(1,3)$ & & \\
\hline & & Interior & 2 & $(1,3)$ & & \\
\hline & \multirow[t]{3}{*}{ Mulch } & Exterior & 2 & $(1,4)$ & \multirow[t]{3}{*}{0.0095} & \multirow[t]{3}{*}{$>0.05$} \\
\hline & & Transitional & 3 & $(1,4)$ & & \\
\hline & & Interior & 3 & $(2,4)$ & & \\
\hline \multirow{6}{*}{ Citrus } & \multirow{3}{*}{ Conventional tillage } & Exterior & 2 & $(1,3)$ & \multirow[t]{3}{*}{$>0.05$} & \multirow[t]{3}{*}{$>0.05$} \\
\hline & & Transitional & 2 & $(1,3)$ & & \\
\hline & & Interior & 2 & $(1,3)$ & & \\
\hline & \multirow{3}{*}{ Mulch } & Exterior & 2.5 & $(1,4)$ & \multirow[t]{3}{*}{$>0.05$} & \multirow[t]{3}{*}{$>0.05$} \\
\hline & & Transitional & 3 & $(1,4)$ & & \\
\hline & & Interior & 3 & $(2,4)$ & & \\
\hline \multirow[t]{6}{*}{ Wheat } & \multirow[t]{3}{*}{ Conventional tillage } & Exterior & 2.5 & $(1,3)$ & \multirow[t]{3}{*}{0.0410} & \multirow[t]{3}{*}{0.0100} \\
\hline & & Transitional & 2 & $(1,3)$ & & \\
\hline & & Interior & 2 & $(1,3)$ & & \\
\hline & \multirow[t]{3}{*}{ Mulch } & Exterior & 3 & $(1,4)$ & \multirow[t]{3}{*}{$>0.05$} & \multirow[t]{3}{*}{$>0.05$} \\
\hline & & Transitional & 2 & $(1,4)$ & & \\
\hline & & Interior & 3 & $(2,4)$ & & \\
\hline
\end{tabular}

Organic $\mathbf{C}$ and water repellency distribution in soil aggregates

A. Jordán et al.

Title Page

Abstract

Introduction

Conclusions

References

Tables

Figures

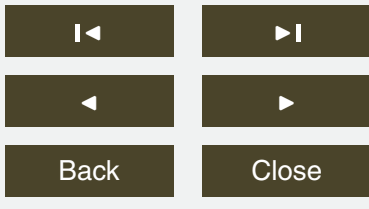

Full Screen / Esc

Printer-friendly Version

Interactive Discussion 


\section{SOILD}

$1,295-325,2014$

Organic $\mathbf{C}$ and water repellency

distribution in soil aggregates

Table 7. Median vales and ranges (between parentheses) of slaking classes determined in aggregates from soil samples under each crop and treatment. Differences between medians from aggregates under different treatments were significant for all crops (Wilcoxon $p$ value $=0.0000$ ).

\begin{tabular}{llrl}
\hline Crop & Treatment & $N$ & Slaking \\
\hline Apricot & Conventional tillage & 30 & $3(2,4)$ \\
& Mulch & 30 & $4(3,6)$ \\
\hline Citrus & Conventional tillage & 30 & $3(2,4)$ \\
& Mulch & 30 & $4(4,6)$ \\
\hline \multirow{2}{*}{ Wheat } & Conventional tillage & 30 & $4(3,5)$ \\
& Mulch & 30 & $5(4,6)$ \\
\hline All cases & & 180 & $4(2,6)$ \\
\hline
\end{tabular}

Title Page

Abstract

Introduction

Conclusions

References

Tables

Figures

14

4

Back

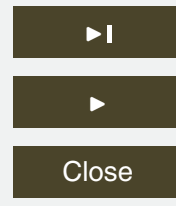

Full Screen / Esc

Printer-friendly Version

Interactive Discussion 
Table 8. R-Spearman coefficients for slaking/EPT, slaking/OC and EPT/OC. $N$ is 180 (all cases) and 30 (groups).

\begin{tabular}{llrrr}
\hline Crop & Treatment & Slaking/EPT & Slaking/OC & EPT/OC \\
\hline \multirow{2}{*}{ Apricot } & Conventional tillage & $0.7111^{*}$ & 0.0913 & 0.2272 \\
& Mulch & $0.9387^{\star}$ & 0.2526 & 0.1908 \\
\hline Citrus & Conventional tillage & $0.8686^{\star}$ & -0.0901 & -0.0117 \\
& Mulch & $0.9949^{\star}$ & 0.0558 & 0.0456 \\
\hline \multirow{2}{*}{ Wheat } & Conventional tillage & 0.0089 & 0.2142 & -0.1995 \\
& Mulch & $0.9919^{\star}$ & -0.0323 & -0.0320 \\
\hline All cases & & $0.8699^{\star}$ & $0.5245^{\star}$ & $0.4317^{*}$ \\
\hline
\end{tabular}

\section{SOILD}

1, 295-325, 2014

Organic $\mathbf{C}$ and water repellency

distribution in soil aggregates

A. Jordán et al.

Title Page

Abstract

Introduction

Conclusions

References

Tables

Figures

${ }^{*} P$ value $\leq 0.0 .5$.

\section{Close}

Back

Printer-friendly Version

Interactive Discussion 


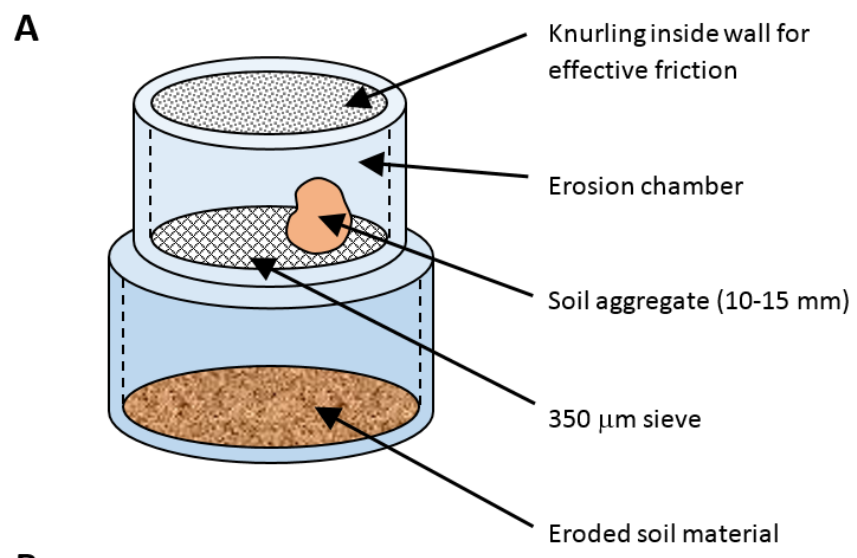

SOILD

B

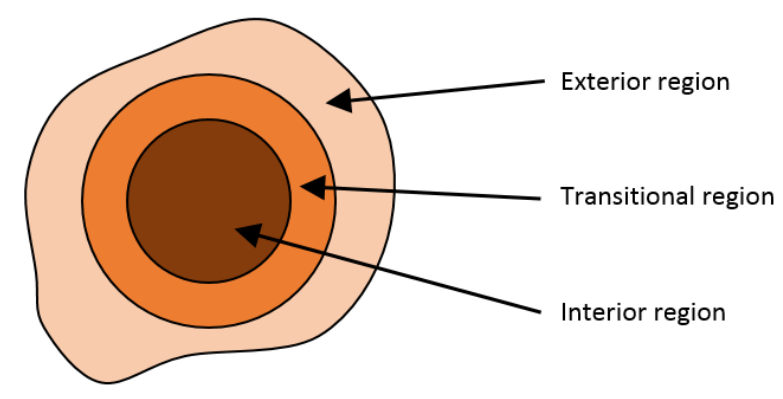

Soil aggregate

$1,295-325,2014$

\section{Organic $\mathbf{C}$ and water repellency \\ distribution in soil aggregates}

A. Jordán et al.

Title Page

Abstract

Introduction

Conclusions

References

Tables

Figures



Full Screen / Esc

Figure 1. (a) Diagram of the soil aggregate erosion chamber system (re-drawn from Park and Smucker, 2005). (b) Layers obtained by abrasion of soil aggregates.

Printer-friendly Version

Interactive Discussion

(c) (i) 

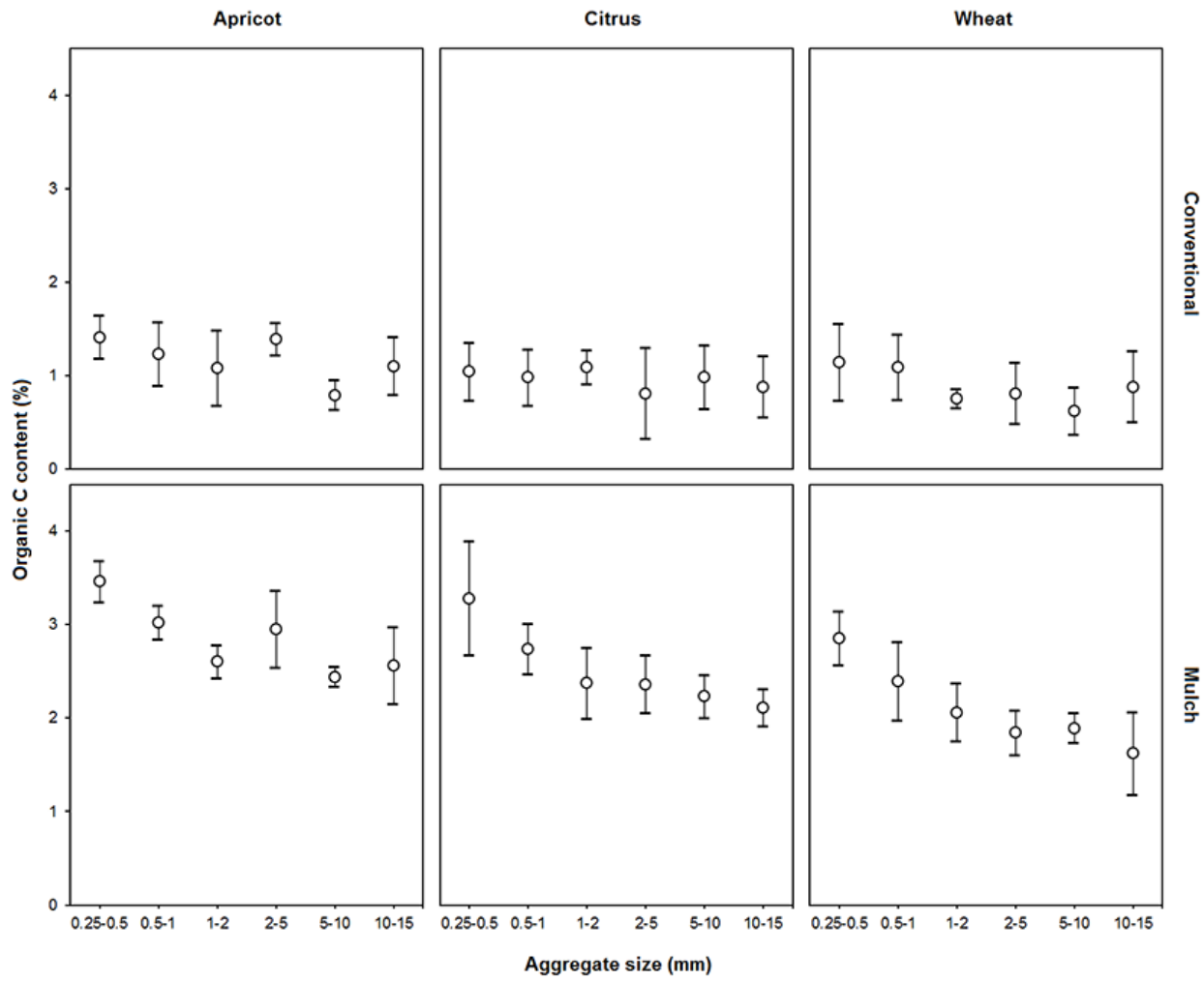

Figure 2. Mean $\mathrm{OC}$ content from each size fraction for soils under each crop (columns) and treatment (rows). Vertical bars show \pm standard deviation.

\section{SOILD}

$1,295-325,2014$

Organic $\mathbf{C}$ and water repellency

distribution in soil aggregates

A. Jordán et al.

\section{Title Page}

Abstract

Introduction

Conclusions

References

Tables

Figures

14

4

Back

Full Screen / Esc

Printer-friendly Version

Interactive Discussion 

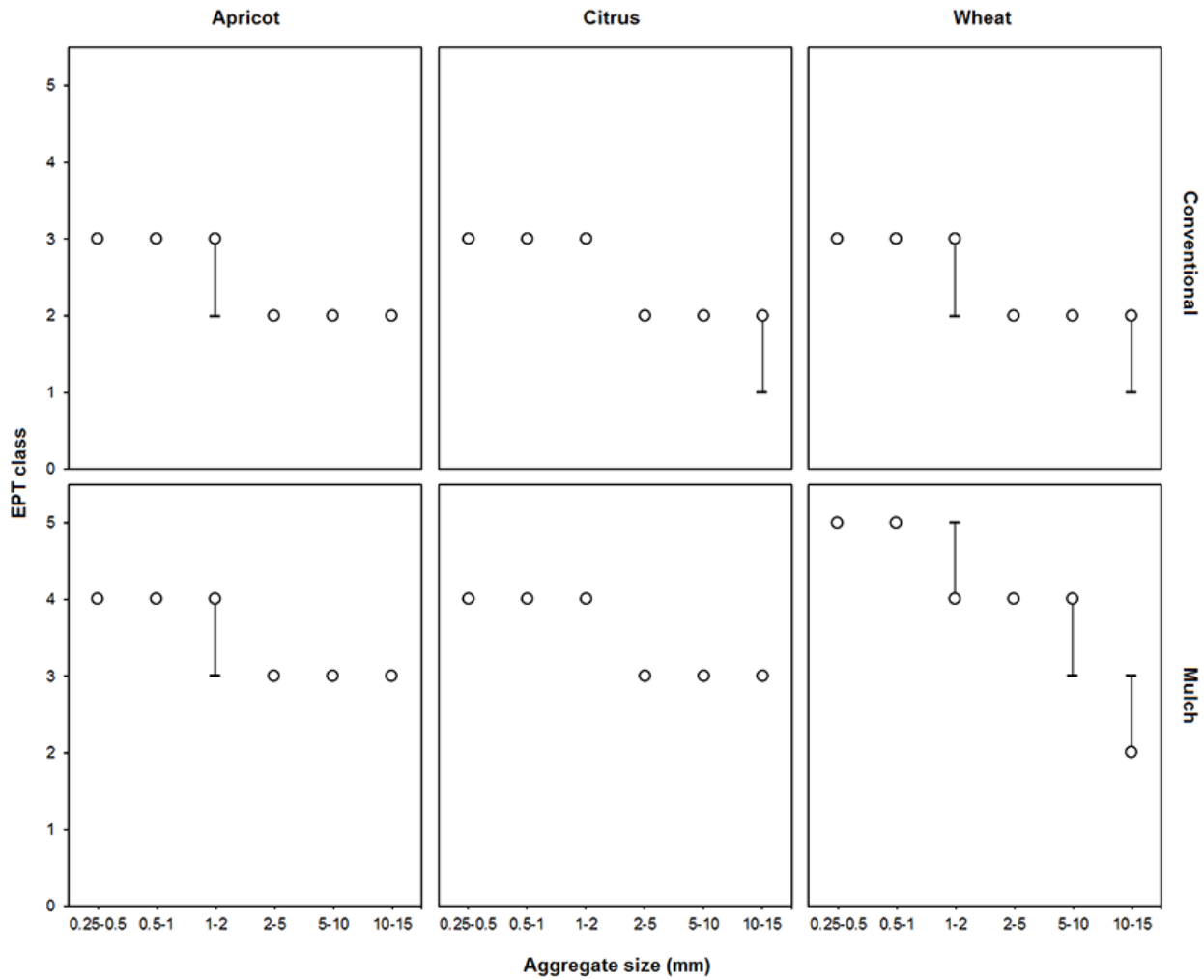

Figure 3. Intensity of WR (median EPT class) from each size fraction for soils under each crop (columns) and treatment (rows). Vertical bars show the range of variation.

\section{SOILD}

$1,295-325,2014$

Organic $\mathbf{C}$ and water repellency

distribution in soil aggregates

A. Jordán et al.

\section{Title Page}

Abstract

Introduction

Conclusions

References

Tables

Figures

14

4

Back

Full Screen / Esc

Printer-friendly Version

Interactive Discussion 